\title{
Peripheral oxygen saturation is not influenced by the use of face masks in exercise
}

\section{A saturação periférica de oxigênio não é influenciada pelo uso de máscaras faciais em exercício}

(D) Natália Cristina de Oliveira Vargas e Silva ${ }^{1}$, ${ }^{\text {Dábio Marcon Alfieri }}{ }^{1}$

\footnotetext{
1 Master Program in Health Promotion Undergraduation in Physical Education, Centro Universitário Adventista de São Paulo - UNASP

Address for correspondence

Fábio Marcon Alfieri

E-mail: fabio.alfieri@unasp.edu.br

Submitted: June 24, 2020

Accepted: October 6, 2020

How to cite

Silva NCOV, Alfieri FM. Peripheral oxygen saturation is not influenced by the use of face masks in exercise. Acta Fisiatr. 2020;27(3):190 192.
}

DOI: $10.11606 /$ issn.2317-0190.v27i3a171415

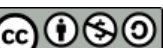

(c)2020 by Acta Fisiátric

This work is licensed under a Creative Commons Attribution 4.0 International

\begin{abstract}
In many cities worldwide the use of face masks in public spaces became mandatory to prevent dissemination of COVID-19. The closure of public parks, gymnasiums and other areas designed for the practice of physical exercise may contribute do inactivity. Objective: The aim of this experience report was to evaluate peripheral oxygen saturation with the use of different face masks at rest and at outdoor exercise. Methods: A single healthy female subject (41 years old, body mass index $18.5 \mathrm{~kg} / \mathrm{m} 2$ ), experienced in outdoor jogging, was subjected to running sessions with 4 different types of face masks (surgical, double cloth, triple cloth and N95) and without mask, in 5 non-consecutive days. Sessions lasted 50 minutes, where $5,8 \mathrm{~km}$ were covered at an average speed of $7 \mathrm{~km} / \mathrm{h}$. Peripheral oxygen saturation ( $\mathrm{SpO} 2, \%)$ and heart rate $(\mathrm{HR}, \mathrm{bpm})$ were registered at rest, at every 5 minutes of exercise and after 5 minutes of recovery. Results: Data revealed that no desaturation occurred at any moment with any mask, even at high intensity. There were no differences in mean SpO2 or HR with either type of face mask during exercise when compared to the use of no mask. Conclusion: Setting aside the discomfort of training with face masks and the possible interference of this in performance, face masks seem not to prevent adequate gas exchange during exercise in healthy subjects.
\end{abstract}

Keywords: Exercise, Oxygen Level, Masks, Coronavirus Infections

\section{RESUMO}

Em muitas cidades do mundo o uso de máscaras faciais em espaços públicos tornou-se obrigatório para prevenir a disseminação da COVID-19. O fechamento de parques públicos, academias e outras áreas destinadas à prática de atividade física podem contribuir para o sedentarismo. Objetivo: Avaliar a saturação periférica de oxigênio com o uso de diferentes máscaras faciais em repouso e durante exercício ao ar livre. Método: Uma única participante (41 anos, índice de massa corporal $18.5 \mathrm{~kg} / \mathrm{m} 2$ ), experiente em corrida ao ar livre, foi submetida a sessões de corrida com 4 tipos diferentes de máscaras faciais (cirúrgica, tecido duplo, tecido triplo e N95) e sem máscara, em 5 dias não consecutivos. As sessões tiveram duração de 50 minutos, onde 5,8km eram percorridos em uma velocidade média de $7 \mathrm{~km} / \mathrm{h}$. A saturação periférica de oxigênio ( $\mathrm{SpO} 2, \%$ ) e a frequência cardíaca ( $F C$, bpm) firam registradas em repouso, a cada 5 minutos de exercício e após 5 minutos de recuperação. Resultados: Os dados revelaram que não ocorreu desaturação em nenhum momento com qualquer das máscaras, mesmo em alta intensidade. Não houve diferença nas médias de SpO2 ou FC com nenhuma das máscaras durante o exercício quando comparadas com o uso de nenhuma máscara. Conclusão: Deixando de lado o desconforto de treinar com máscaras faciais e a possível interferência disso na performance, as máscaras faciais parecem não impedir uma adequada troca gasosa durante o exercício em indivíduos saudáveis.

Palavras-chave: Exercício Físico, Nível de Oxigênio, Máscaras, Infecções por Coronavirus 
In December 2019, transmission of the novel coronavirus that causes coronavirus disease (COVID-19) progressed in China and the virus began to be transmitted from person to person. ${ }^{1}$ Restrictive measures imposed undesirable changes in lifestyle of most individuals, especially the ones suffering from non-communicable chronic diseases (NCCD). ${ }^{2}$

Physical exercise has been shown effective to counteract most NCCD, with direct effects on both mental and physical health. ${ }^{2}$ Special attention must be payed to the elderly population group, as additional benefits such as the prevention of falls, sarcopenia and cognitive impairment may arise from the regular practice of exercise. ${ }^{3}$

It is recommended that people do not interrupt their physical activities during the social isolation period, as it is substantive not only for the health of the overall population, but especially for those with additional risk factors, like NCCD or older age. ${ }^{2}$

In many cities worldwide the use of face masks in public spaces became mandatory to prevent the spread of the infection. ${ }^{4}$ Together with the closure of public parks, gymnasiums and shared areas in residential buildings, this may negatively impact the practice of physical activities.

Thus, the aim of this experience report was to evaluate peripheral oxygen saturation with the use of different face masks at rest and at outdoor exercise. Our hypothesis was that the use of face masks would impair proper ventilation and contribute to oxygen desaturation in high intensity exercise.

A single healthy female subject (41 years old, body mass index $18.5 \mathrm{~kg} / \mathrm{m}^{2}$ ), experienced in outdoor jogging, was subjected to running sessions with 4 different types of face masks (surgical, double cloth, triple cloth and N95) and without mask, in 5 non-consecutive days. Sessions lasted 50 minutes, where $5,8 \mathrm{~km}$ were covered at an average speed of $7 \mathrm{~km} / \mathrm{h}$. Peripheral oxygen saturation (\%) and heart rate (bpm) were registered at rest, at every 5 minutes of exercise and after 5 minutes of recovery with IMFtec-A pulse oximeter (Guangdong, China). Data were analyzed with one-way ANOVA in SPSS v.24 for Windows.

Data on $\mathrm{SpO} 2$ and $\mathrm{HR}$ at rest, at peak exercise and at recovery, as well as minimum and maximal values of $\mathrm{SpO} 2$ in each condition, are shown in Table 1.

Considering desaturation as a decrease in 4 or more percentage points in relation to resting values, ${ }^{5}$ our data revealed that absolutely no desaturation occurred at any moment. As resting $\mathrm{SpO}_{2}$ was $98 \%$ in all occasions, and minimum registered $\mathrm{SpO}_{2}$ was $96 \%$, this represents a decrease of 2 percentage points only.

Table 2 shows that there were no differences in mean $\mathrm{SpO} 2$ or HR with either type of face mask during exercise when compared to the use of no mask.

Mean HR registered during exercise represents an average of $84.9-88.3 \%$ of maximal HR, which stands for a high intensity exercise. ${ }^{6}$ Even at this intensity, desaturation did not occur. Although patients with pulmonary fibrosis or pulmonary arterial hypertension may experience oxygen desaturation in submaximal exercise, it is rather uncommon in healthy persons, as physical exercise improves ventilation an alveolar recruitment. $^{7}$

Oxygen desaturation is more pronounced in whole body exercises and in exercises with lower limbs (as it is the case of running), as the amount of muscle mass involved may influence the development of exercise hypoxia even in healthy individuals. $^{8}$ Exercise-induced hypoxia is multifactorial: the presence of obesity, reduced lung capacity, reduced diffusion capacity, ventilation or oxygen transport impairments may all interfere in oxygen saturation8. In the present study, involving a healthy subject, this was not observed with any type of face mask, consequently we refuse our original hypothesis.

This study has some limitations. Due to the several difficulties to conduct field research during the COVID-19 pandemics, this was an experience report conducted with a single subject and may not reflect population data. Subject was an experienced runner; hence our findings may not replicate the condition of sedentary, elderly persons or the ones with NCCD.

Table 1. Absolute values of peripheral oxygen saturation and heart rate at rest, at peak exercise and at recovery with different masks

\begin{tabular}{|c|c|c|c|c|c|c|c|c|}
\hline \multirow{2}{*}{ Mask } & \multicolumn{2}{|c|}{ Rest } & \multicolumn{2}{|c|}{$\begin{array}{c}\text { Peak } \\
\text { exercise }\end{array}$} & \multicolumn{2}{|c|}{ Recovery } & \multicolumn{2}{|c|}{ SpO2 } \\
\hline & SpO & $H R$ & $\mathrm{SpO}$ & $\mathrm{HR}$ & $\mathrm{SpO}$ & $\mathrm{HR}$ & $\min$ & $\max$ \\
\hline None & 98 & 84 & 98 & 168 & 98 & 103 & 97 & 99 \\
\hline Surgical & 98 & 76 & 98 & 172 & 99 & 109 & 96 & 99 \\
\hline Double cloth & 98 & 83 & 98 & 177 & 98 & 108 & 97 & 99 \\
\hline Triple cloth & 98 & 103 & 99 & 169 & 98 & 105 & 98 & 99 \\
\hline N95 & 98 & 92 & 98 & 173 & 98 & 108 & 96 & 98 \\
\hline
\end{tabular}

HR: heart rate; SpO2: peripheral oxygen saturation; min: minimum; max maximal. Data are expressed as means \pm standard deviations. SpO2 values are expressed in percentages (\%). HR values are expressed in beats per minute (bpm)

Table 2. Comparison of mean peripheral oxygen saturation and heart rate with different masks at exercise

\begin{tabular}{lcccc}
\hline \multicolumn{1}{c}{ Mask } & SpO2 (\%) & p & HR (bpm) & p \\
\hline None & $98.3 \pm 0.7$ & 0.08 & $156.9 \pm 18.0$ & 0.90 \\
Surgical & $98.2 \pm 0.9$ & & $152.4 \pm 18.9$ & \\
Double cloth & $98.1 \pm 0.5$ & & $156.1 \pm 15.4$ & \\
Triple cloth & $98.4 \pm 0.5$ & & $152.6 \pm 15.0$ & \\
N95 & $97.4 \pm 1.2$ & & $157.8 \pm 8.9$ & \\
\hline
\end{tabular}

\section{Final Comments}

To the best of our knowledge, this is the first study involving the use of face masks during outdoor exercise, however this may become a reality as far as the pandemics lasts. Setting aside the discomfort of training with face masks (as they get wet, create a warm environment around the mouth and nose, and may also increase nasal secretions) and the possible interference of this in performance, face masks seem not to prevent adequate gas exchange during exercise in healthy subjects.

\section{Acknowledgement}

We thank Prof. MSc. Leslie Andrews Portes and Prof. MSc. Flávio André Silva from the Exercise Physiology Laboratory (LAFEX-UNASP) for granting the pulse oximeter used in this 
research, and for their valuable reflections on the topic addressed herein.

\section{REFERENCES}

1. Huang C, Wang Y, Li X, Ren L, Zhao J, Hu Y, et al. Clinical features of patients infected with 2019 novel coronavirus in Wuhan, China. Lancet. 2020;395(10223):497-506. Doi: https://doi.org/10.1016/S0140-6736(20)30183-5

2. Jiménez-Pavón D, Carbonell-Baeza A, Lavie CJ. Physical exercise as therapy to fight against the mental and physical consequences of COVID-19 quarantine: Special focus in older people. Prog Cardiovasc Dis. 2020;63(3):386-388. Doi: https://doi.org/10.1016/j.pcad.2020.03.009

3. Martínez-Velilla N, Casas-Herrero A, Zambom-Ferraresi F, Sáez de Asteasu ML, Lucia A, Galbete A, et al. Effect of exercise intervention on functional decline in very elderly patients during acute hospitalization: a randomized clinical trial. JAMA Intern Med. 2019;179(1):28-36. Doi: https://doi.org/10.1001/jamainternmed.2018.4869
4. Feng S, Shen C, Xia N, Song W, Fan M, Cowling BJ. Rational use of face masks in the COVID-19 pandemic. Lancet Respir Med. 2020;8(5):434-436. Doi: https://doi.org/10.1016/S2213-2600(20)30134-X

5. Prefaut C, Durand F, Mucci P, Caillaud C. Exercise-induced arterial hypoxaemia in athletes: a review. Sports Med. 2000;30(1):47-61. Doi: https://doi.org/10.2165/00007256200030010-00005

6. Katch VL, McArdle WD, Katch F. Essentials of exercise physiology. $4^{\text {th }}$ ed. Baltimore: Wolters Kluwer, Lippincott Williams and Wilkins; 2011.

7. Seixas DM, Seixas DM, Pereira MC, Moreira MM, Paschoal IA. Dessaturação em indivíduos saudáveis submetidos ao incremental shuttle walk test. J Bras Pneumol. 2013;39(4):440-6. Doi: https://doi.org/10.1590/S180637132013000400007

8. Nielsen HB. Arterial desaturation during exercise in man: implication for $\mathrm{O} 2$ uptake and work capacity. Scand J Med Sci Sports. 2003;13(6):339-58. Doi: https://doi.org/10.1046/j.1600-0838.2003.00325.x 